\title{
Assessment and management of effects of large hydropower projects on aquatic ecosystems in British Columbia, Canada
}

\author{
Michael J. Bradford $(\mathbb{B}$
}

Received: 12 March 2020/Revised: 11 July 2020/Accepted: 20 July 2020/Published online: 29 July 2020

(C) The Author(s) 2020

\begin{abstract}
Most of the hydropower generated in Canada's western province of British Columbia is generated by a small number of large storage or diversion projects that impound large rivers. All but one were built between 1950 and 1985; a period when environmental considerations for large projects were evolving to present-day social, political and regulatory standards. Large projects result in ecosystem transformations; river valleys are converted to reservoirs, and the release of water for power generation results in highly altered flow regimes downstream of dams. I describe the effects of three projects on aquatic ecosystems and measures that have been taken over the past 60 years to monitor and mitigate those effects, with an emphasis on downstream effects to fish populations. I briefly review methods that were used to predict effects, particularly on key fish species, and consider the role of adaptive management and its alternatives on resolving uncertainties about ecological effects of large hydroelectric projects.
\end{abstract}

Guest editors: Ingeborg P. Helland, Michael Power, Eduardo G. Martins \& Knut Alfredsen / Perspectives on the environmental implications of sustainable hydropower

M. J. Bradford $(\bowtie)$

Fisheries and Oceans Canada, Pacific Science Enterprise

Centre, 4160 Marine Drive, West Vancouver,

BC V7V1N6, Canada

e-mail: Mike.Bradford@dfo-mpo.gc.ca
Keywords British Columbia $\cdot$ Hydropower . Environmental flow $\cdot$ Adaptive management

\section{Introduction}

Mountainous terrain and abundant precipitation in British Columbia (BC), Canada's westernmost province, set the stage for the development of an extensive network of hydroelectric power facilities. Hydroelectric generation currently accounts for nearly $90 \%$ of the total power generation in the province, with a total capacity of nearly 15,000 MW (CER, 2017). Electricity is delivered from numerous small $(<50 \mathrm{MW})$ facilities, and fewer larger ones, with the largest stations on the Peace and Columbia Rivers exceeding $1000 \mathrm{MW}$ each. These larger stations account for most of the power generated in the province.

Along with the diversity in size, there is variation in the configuration of power stations. The largest have storage reservoirs that capture spring runoff for yearround generation at powerplants located at the storage dam, or through diversion to powerplants at other locations. Downstream, there may be secondary stations designed to generate additional power from discharges from the storage dam. There are some smaller diversion facilities where water is diverted to a lower elevation location for generation, often in an 
adjacent watershed. Finally, there are many small runof-river stations located in high gradient streams that do not have significant storage, but divert streamflow through penstocks for generation and return flows back to the same river at a location downstream.

British Columbia rivers are home to moderately diverse fish communities that show strong regional variation related to post-glacial connectivity and colonization histories (McPhail, 2007). In most cases interest has tended to focus on salmonid fishes that are sought after in various fisheries, particularly Pacific Salmon for watersheds that drain into the Pacific Ocean, and trout, charr, grayling and whitefish in other areas. Consequently regulatory agencies have directed their attention on effects of the hydroelectric development on these species, although in recent years, the Provincial and Federal species at risk policy and legislation have expanded the scope of regulatory purview.

In this account I focus on three of the larger hydroelectric stations in $\mathrm{BC}$ and describe effects the installation and operation of those facilities has had on fisheries resources, and efforts made to monitor and manage those impacts. Sites were chosen because they were developed at different times, under different regulatory environments, and each had significant riverine fishery resources. Emphasis is on downstream effects below the point of regulation to highlight the challenges of predicting, monitoring and managing changes in large river ecosystems associated with hydropower development. I begin with a brief description of the Canadian regulatory context, then provide a narrative of the development of each project and changes to aquatic environments using both published and technical literature, to draw conclusions about the assessment and management of effects.

\section{Legislative background}

Since the formation of the Canadian confederation in 1867, authority over natural resources, including water, has been delegated to the provinces. Federal jurisdiction has been limited to specific issues, and in the case of hydropower development, federal responsibility for fisheries and fish habitat as set out in Fisheries Act has been central (Saunders \& Wenig, 2007).
When promulgated in 1868, the Fisheries Act was primarily designed for the management of fisheries, but over time, it has been amended to include sections related to the protection of fish habitat from physical disturbance or pollution (Benidickson, 2017). The original act contained provisions for the Minister of Fisheries (or their officials) to order measures to allow for the passage of fish past barriers. Subsequent amendments enabled the Minister to order the use of screens (s. 20; 1894) and to order sufficient flow for both the passage of fish and to protect spawning grounds below dams or barriers (s. 22; 1932).

Hydroelectric development in British Columbia began in the early 1900s, and facilities constructed during the first half of that century made little provision for fisheries or environmental concerns despite the presence of the limited legal tools contained in the Fisheries Act. Dams were constructed on a number of coastal streams that were home to salmon populations, yet no structures to allow the passage of migrating salmon upstream or downstream of dams were installed. In some cases, little or no flow was released below diversion dams (Hirst, 1991). These factors lead to the imperilment or extirpation of a number of small salmon populations.

Similarly, legal means were also not exercised during the development of proposals for larger hydroelectric projects in British Columbia during the mid-twentieth century (Evendon, 2004). Rather, the siting and design of projects were the result of negotiations between proponents, governments, and in some cases the salmon fishing industry; notably absent were the indigenous peoples whose traditional and ancestral territories were affected by these projects (Windsor \& McVey, 2005). Outcomes were variable with respect to resulting effects on fish populations. However, by the 1950s the capacity of aquatic research agencies increased, notably the Fisheries Research Board of Canada and the International Pacific Salmon Fisheries Commission. Directed studies on the effects of dams and reservoirs on aquatic ecosystems occurred at this time (e.g. Brett, 1957; Geen, 1974). That work led to some of the more ambitious and potentially disruptive water management schemes being withdrawn (such as mainstem dams on the Fraser River, the most important salmon producing river in $\mathrm{BC}$ ), and greater consideration given to the modification of other facilities to reduce impacts on salmon and other fishes. The first habitat 
compensation projects were also constructed, which were salmon spawning channels to offset effects of habitat alteration or destruction resulting from hydropower development (MacKinnon et al., 1961).

The management of effects of development projects on fish and fish habitat in Canada changed significantly in 1977 when explicit provisions for the protection of fish habitat were added to the Fisheries Act. In 1986 the landmark Policy for the Management of Fish Habitat (DFO, 1986) set out the means for administrating the new fish habitat protection sections of the Act. The Policy introduced the guiding principle of No Net Loss of productive capacity of habitat as a result of efforts to protect, restore and create habitat. The policy had a stated preference for measures that first avoid, then mitigate, and finally compensate (or offset) unavoidable effects, now known as the mitigation hierarchy (McKenney \& Kiesecker, 2010). Revisions to the habitat protection sections of the Act occurred in 2012 and 2019 and new policies have been introduced; in general, the recent revisions permit a more flexible approach to the application of the mitigation hierarchy (DFO, 2019).

For many developments that affect fish habitat, the goal of balancing unavoidable losses of fish habitat or fisheries productivity with gains resulting from compensation or offsetting measures is usually attained by like-for-like compensation based on the area of the affected habitat (Clarke \& Bradford, 2014). Such an approach is infeasible for large hydroelectric developments that result in the conversion of rivers to reservoirs and can trigger significant changes in river environments as a result of altered hydrological regimes or the diversion or augmentation of flows (DFO, 2014a). The hydroelectric industry in Canada has generally favoured a population-based approach to assessing effects and designing offsetting measures where gains and losses can be evaluated on the basis of changes in abundance of key species, or in patterns of human use of species in waterbodies created or modified by development (Bérubé et al., 2005; CHA, 2016). The current policy for the application of the habitat protection provisions of the Fisheries Act allows the Minister to consider the effects of the project on the productivity of the relevant fisheries and local fisheries management objectives when contemplating the issuance of an authorization for activities that could result in alterations to habitat, death of fish, or changes in passage or flow in a river (DFO, 2019).
New hydroelectric developments are subject to other polices and legislation, including results of provincial or federal environmental assessment processes, provincial water and pollution legislation, the federal Species at Risk Act (SARA) and others. These have generally played a lesser role than the Fisheries Act for the management of impacts on aquatic habitats and fish populations, except for those cases where there are populations that are listed as endangered or threatened under SARA.

\section{Three case histories}

In the following sections, I briefly describe the development of three of the larger hydroelectric stations in $\mathrm{BC}$, with a focus on the management and assessment of effects on fish habitat and fish populations, particularly in downstream river environments.

\section{Nechako River}

In an effort to expand industrial development in northern BC, in 1950 the Provincial Government entered into an agreement with the aluminium company Alcan for a hydroelectric development on the Nechako River, a tributary of the Fraser River that has a mean annual discharge (MAD) of about $200 \mathrm{~m}^{3} \mathrm{~s}^{-1}$ (Fig. 1). The development resulted in construction of a mainstem dam in the upper Nechako River, the creation of a large reservoir, and the diversion of flow from the Nechako River westward to a coastal inlet, where the power could be generated for an aluminium smelter located in the coastal community of Kitimat. At the time, fisheries agencies recognized the risks that reduced flow in the Nechako River posed for chinook salmon (Oncorhynchus tshawytscha) that spawned in the river downstream of the dam, and for sockeye salmon $(O$. nerka) populations that spawned in the river, or used it as a migratory corridor to access other spawning areas (IPSFC, 1953). The agencies were unsuccessful in their attempts to modify the project in a way that would reduce those risks (Evenden, 2004).

Once the dam was closed in 1954, freshet flows in the Nechako River were greatly reduced, and geomorphological changes to the channel began. These include the encroachment of woody vegetation on gravel bars, the narrowing of the channel, and the isolation of side- and off-channel habitats (Rood, 


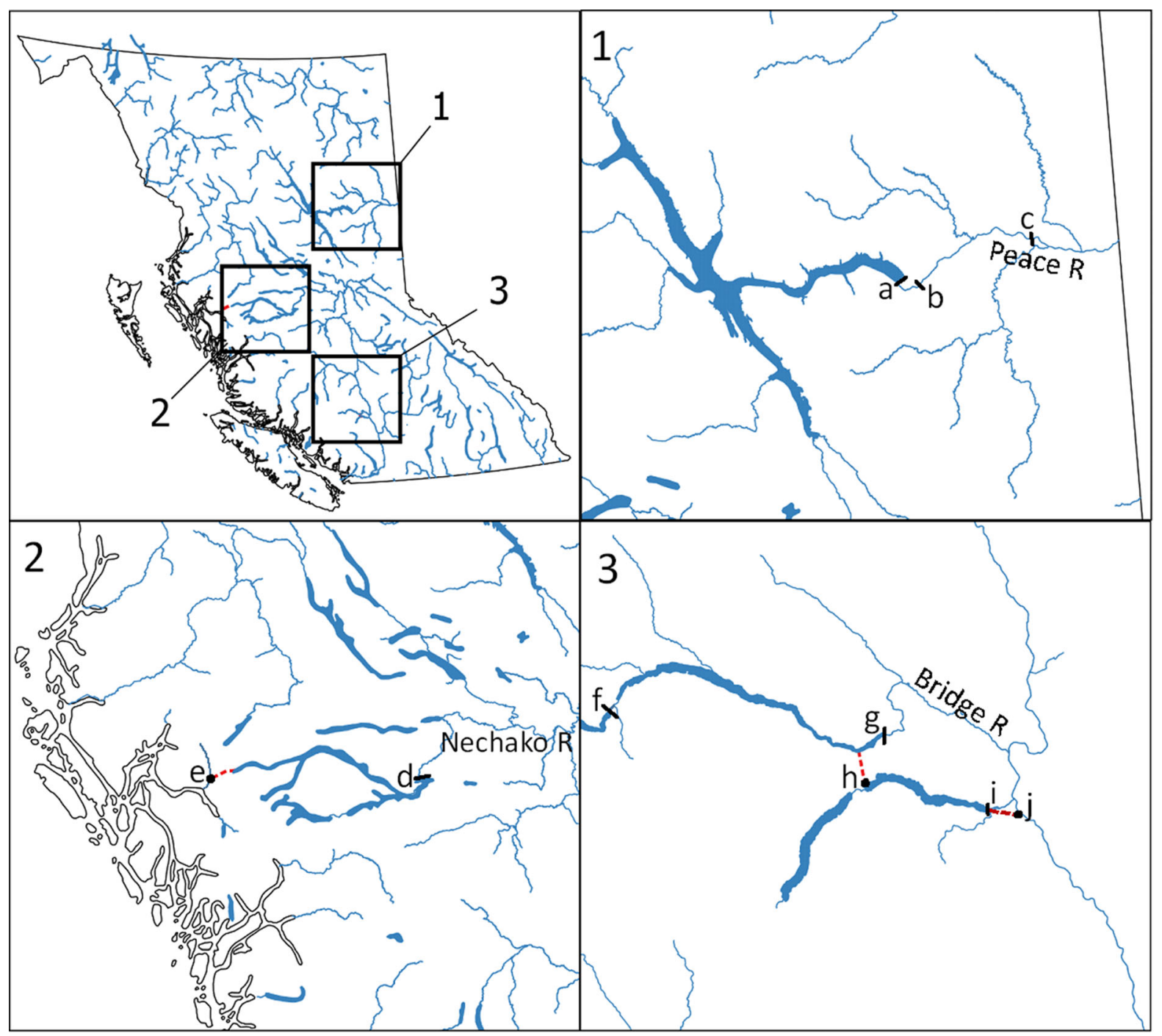

Fig. 1 Map of British Columbia, Canada, showing the location of the 1 Peace, 2 Nechako and 3 Bridge-Seton hydroelectric systems. Shown are the WAC Bennet Dam (a), Peace Canyon Dam $(b)$, Site C Dam (under construction, $c$ ) on the mainstem of the Peace River; the Kenney Dam $(d)$ on the Nechako River that

1987). Monitoring of salmon populations prior to, and after, the construction of the dam was inadequate to quantitatively assess whether there had been effects of flow regulation on the abundance of chinook salmon spawners, although observations suggests reduced abundances in the two decades after dam closure (Jaremovic \& Rowland, 1988). Assessing the effects of habitat change using adult salmon abundance is always challenging because abundance is the result of survival not only freshwater habitats but also results in diversion of generation flows to the Kemano Powerhouse (e); and the Lajoie $(f)$ and Terzaghi Dams $(g)$ on the Bridge River, the Bridge Powerhouse $(h)$ and Seton Dam (i) on Seton Lake, and the Seton Powerhouse ( $j$ )

conditions during their migration and marine phases, and the rate of fishery removals. These factors can confound the analysis of effects in freshwater (Mundie \& Bell-Irvine, 1986).

In 1979, a combination of low reservoir inflows (due to low snowpack), and increased demand for electricity (Alcan now had the capacity to sell surplus power to the Province) resulted in the release of much smaller volumes of water into the Nechako River than had been the case since the system was commissioned 
and the reservoir filled. In 1980, the Minister of Fisheries invoked section 20 of the Fisheries Act (1970) and used a court-ordered injunction to secure the release of water deemed sufficient for chinook and sockeye salmon populations (BCUC, 1994). This included a minimum flow to maintain chinook salmon spawning and juvenile rearing habitats, and a larger release in mid-summer to assist in cooling the lower Nechako River, to allow for the safe passage of sockeye salmon migrating upstream to their spawning areas (Fig. 2).

In the mid-1980s Alcan began planning the final stages of their project that would result in an increase in generation capacity, derived in part from the diversion of a greater proportion of flows from the Nechako River (Mundie \& Bell-Irvine, 1986). Alcan launched a legal challenge of the use of section 20 of the Fisheries Act (1970) and that resulted in an out-ofcourt settlement in 1987 that allowed the expansion of the project to proceed. The settlement included a reduction in flows in the Nechako River below those

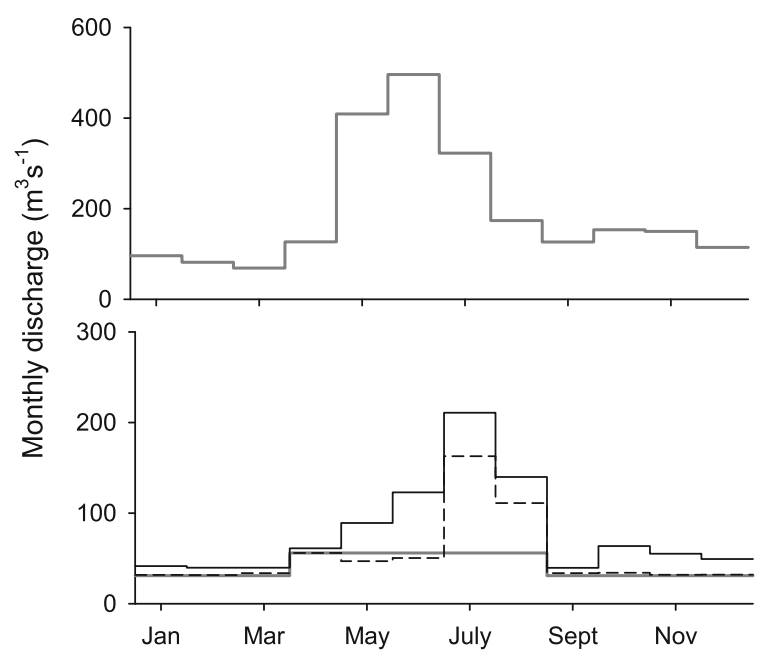

Fig. 2 Average monthly flows in the Nechako River. Top: inflows to the Nechako Reservoir (1955-2006; Alcan, 2007) which are approximately equivalent to unregulated flows in the upper Nechako River. Bottom: average regulated releases into the Nechako River (Water Survey of Canada [WSC] Station 08JA017). Solid grey line is the minimum flow prescribed for the conservation of chinook salmon; not shown are additional cooling flows that are periodically required in July and August to meet temperature criteria for migrating sockeye salmon. Dashed line: actual flows 1979-1995, a period when flows were close to the required minimum flows. Increased flow in July and August is the average cooling flow. Solid black line: flows for 1996-2019, a period when average reservoir releases exceeded minimum required flows in most months specified in the DFO injunction once the project was completed. Given concerns about the risk such low flows posed, an adaptive management program was developed that included monitoring of multiple life stages of chinook salmon in the river, and the potential use of non-flow remediation measures if adult salmon abundance fell below a target range (BCUC, 1994).

Project construction and the enhanced monitoring program began in the late 1980s but increased public concerns about effects on the Nechako River resulted in a public hearing (BCUC, 1994) and the cancellation of the project expansion by the Provincial government in 1995. Nonetheless, monitoring and the adaptive management programs continued in order to provide insight on the adequacy of the "injunction flows" that were instituted in 1980. Bradford (1994) suggested low flows in the upper Nechako River may have contributed to a decline in chinook salmon abundance, and hypothesized that altered thermal regime resulting from impoundment could be the mechanism. Since the 1990s chinook salmon abundance has generally been increasing although there have been some years when returns to the Nechako River that have fallen below the target range. Results from monitoring studies provided no indication that conditions in the river itself contributed to low returns (NFCP, 2005). Since 1997, average flow releases into the Nechako River have periodically exceeded the minimum required flows, resulting in higher average flows than 1980-1996 period (Fig. 2); however, potential effects on salmon abundance have yet not been analysed. Aspects of the enhanced monitoring program were wound down during the 2010s as the status of the chinook salmon population was deemed acceptable in terms of the performance criteria that had been developed, and there were no immediate plans to change the flow regime from that specified in 1980 (NFCP, 2005, 2016).

The fisheries conservation landscape for the Nechako River changed in the late 1990s when investigations revealed recruitment failure for the white sturgeon population (Acipenser transmontanus) that inhabits the watershed. The population consists of only a few hundred individuals and has been assessed as endangered (COSEWIC, 2012). The exact cause of decline has not be identified, but the timing of recruitment failure is coincident with the construction of the hydroelectric facility. Altered flow, temperature, and sediment regimes have all been hypothesized 
as contributing factors (Korman \& Walters, 2000; Hildebrand et al., 2017), and research is ongoing to identify appropriate remedial measures. At present, no changes to the flow regime that was established for the conservation of salmon have been instituted for the protection of sturgeon.

\section{Bridge River}

The Bridge River (MAD $100 \mathrm{~m}^{3} \mathrm{~s}^{-1}$ ) is supplied by glaciers of the Coast Range, and drains into the Fraser River in south-central BC. It runs parallel to the much lower elevation Seton River basin (Fig. 1), and the potential to divert water from the Bridge to the Seton watershed for electrical generation was recognized in the early 1900s. The Bridge-Seton hydroelectric system was fully developed in the 1950s to meet rapidly increasing electrical demands, particularly in the Vancouver area (Evenden, 2004). The system consists of two mainstem dams in the Bridge River, diversion tunnels from the Bridge to the Seton watershed, a dam at the outlet of Seton Lake, and power generation facilities near the Fraser River (Hirst, 1991).

At the time this project was being contemplated, the increasing recognition of effects of hydropower development on Pacific salmon populations (Brett, 1957) resulted in some measures were taken in the design of the Bridge-Seton project to mitigate impacts. In particular, a fish ladder was constructed at the Seton Lake Dam to allow upstream passage of adult salmon, and flows to protect fisheries resources in the Seton River were established. Two salmon spawning channels were constructed to offset the loss of habitat due to the Seton Lake Dam (Hirst, 1991). However, in the Bridge River, the newly created reservoir flooded some of the best salmon habitat in the watershed, and no provision for fish passage was provided. There was no continuous water release below Terzaghi dam, resulting in the dewatering of $4 \mathrm{~km}$ of the lower Bridge River. Inflows from small tributaries and groundwater sources below the dam resulted in flows that were $<2 \%$ of the natural flows prior to diversion (Fig. 3). Salmon populations that were excluded from the historical spawning areas were forced to make use of the greatly diminished lower Bridge River, although absence of pre-development data prevents an assessment of changes in population size and diversity that

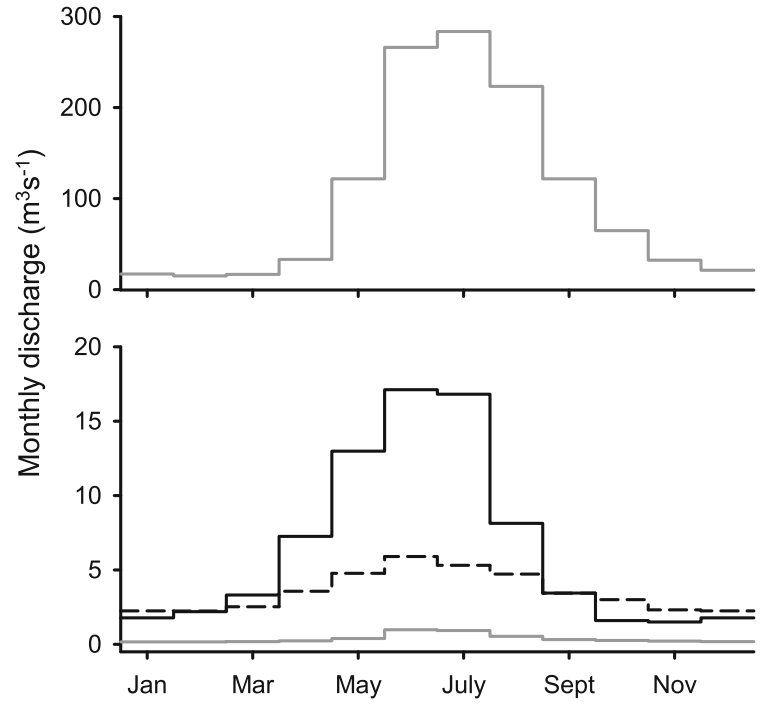

Fig. 3 Average monthly flows in the Bridge River. a Historical flows prior to regulation (1914-1947; WSC 08ME001). b Post regulation flows at a point $9 \mathrm{~km}$ downstream of Terzaghi Dam; note change in scale between panels (Bradford et al., 2011). Solid grey line: flows prior to 2000, resulting from groundwater and inputs from small tributary streams; dashed line: first experimental trial (2000-2008) based on a annualized reservoir release equivalent to $3 \mathrm{~m}^{3} \mathrm{~s}^{-1}$; solid black line: second flow trial (2009-2015) based on a water budget of $6 \mathrm{~m}^{3} \mathrm{~s}^{-1}$

may have occurred with the development of the project.

As a result of pressures from fisheries agencies and First Nations in the 1990s modifications were made to Terzaghi dam for a continuous hypolimnetic flow release to allow the rewatering of the channel immediately below the dam, and the augmentation of the residual flows further downstream. A technical team was tasked with determining an appropriate amount of flow and they recognized that this would be a suitable setting for an adaptive management (AM) experiment. Results from a decision analysis suggested uncertainties in the flow-fish relation were large enough to warrant an experimental approach (Failing et al., 2004).

The original experimental design consisted of three different flow releases plus the baseline (no release), with 4-5 years of data collected at each flow release. Each flow treatment was based on an annual water budget but seasonal variation in flows to mimic the natural flow regime was incorporated (Fig. 3). The total biomass of juvenile salmonids was considered as the key performance indicator, although secondary 
indicators were also developed as measures of ecosystem performance. Flow releases began in 2000 , but the original experimental design was modified due to ongoing negotiations between First Nations affected by the project and BC Hydro, the project operator (Mullen-Dalmer, 2009). Increased participation by First Nations during the first flow trial resulted in a modified set of objectives that were broader than those established by the original fisheries technical team (Failing et al., 2013). Two experimental flow trials have now been conducted (the first is documented in Bradford et al., 2011); however, the experimental plan was altered again in 2016 due to the need to release much larger volumes of water than was envisioned as a result of infrastructure issues.

Apart from the restoration of the previously dry channel, the results of the first flow releases have been ambiguous with respect to benefits for the total biomass of juvenile salmon (Bradford et al., 2011). However, of particular concern, were declines in the abundance of juvenile chinook salmon compared to the baseline period. It was hypothesized that declines may have been the result of unforeseen effects of small changes in the thermal regime of the river after the flow release that accelerated the development of eggs and larvae. It is not possible to discern the exact cause of the decline from the monitoring data; however, to date no additional investigations have been conducted into the issue.

There are now nearly 25 years of monitoring data for the Bridge River encompassing a wide range of flows and it is anticipated that once the infrastructure issues are resolved it should be possible to determine an appropriate long-term flow regime for this system based on the results of the AM program.

\section{Peace River}

Throughout the mid-twentieth century proposals for mainstem dams on the Fraser River were developed, but the prediction of disastrous consequences for salmon populations contributed to the Provincial Government changing its focus to the Peace and Columbia Rivers, neither of which supported salmon (Evendon, 2004). In the case of the Canadian portion the of the Columbia River, existing salmon populations had already been extirpated by the construction of mainstem dams in the lower river in the United States.
The Peace River drains the eastern slope of the northern Rocky Mountains in BC and flow east and north through Alberta to join the Athabasca River at the Peace-Athabasca Delta. Two mainstem dams, completed in 1968 and 1980 resulted in the creation of a $1780 \mathrm{~km}^{2}$ storage reservoir (Williston Reservoir) and the $8 \mathrm{~km}^{2}$ Dinosaur Reservoir immediately downstream. Flows in the Peace River are primarily regulated by releases from Williston Reservoir as there is little change in reservoir volume in the Dinosaur Reservoir (Fig. 1). Mean annual discharge at the dam sites is about $1100 \mathrm{~m}^{3} \mathrm{~s}^{-1}$. A third mainstem dam, known as Site $\mathrm{C}$, is currently under construction and will convert about $80 \mathrm{~km}$ of river to a third reservoir.

The Peace River dams are load-following or hydropeaking facilities and generation flows generally fluctuate from nightly lows to higher flows during the day. There are currently no environmental flow requirements, other than a minimum flow release $\left(283 \mathrm{~m}^{3} \mathrm{~s}^{-1}\right)$ at the second dam to reduce impacts to downstream habitats from dewatering during hydropeaking. Average flows tend to be higher in the winter than in summer to meet seasonal electricity demand and to balance generation from more seasonal facilities within the provincial hydroelectric network (Fig. 4).

Completion of the first 2 dams resulted in many changes to aquatic ecosystems. The filling of the Williston Reservoir inundated three low gradient river

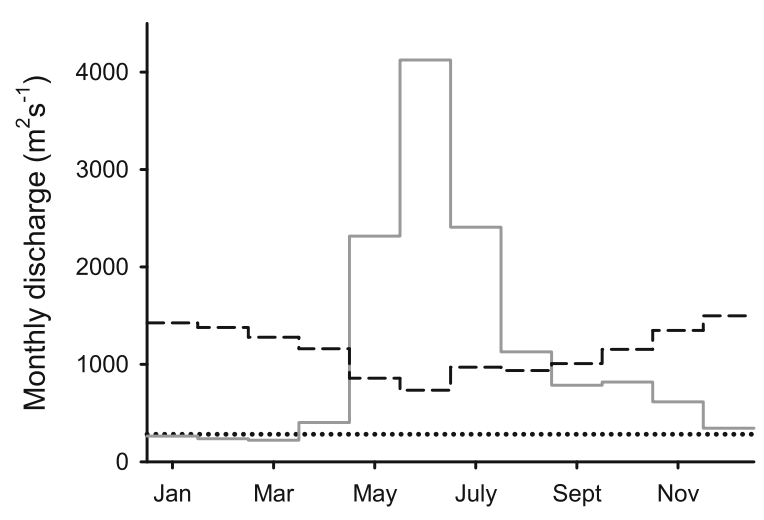

Fig. 4 Average monthly flows in the Peace River downstream of the 2 existing dams (WSC 07EF001). Solid line is preregulation flow (1950-1969), dashed line is regulated flow (1973-2018). As dams on the Peace River are used for hydropeaking and daily flows can vary considerably around the averages shown. Dotted line is the minimum permissible flow established in the 1990 s 
valleys, and the lower reaches of tributary streams in those valleys. Consequently, populations of fluvial Arctic grayling (Thymallus acticus) have become isolated and appear to be in decline (Hawkshaw et al., 2014). The reservoir itself is unproductive (Stockner et al., 2005) but does support a variety of fish species including lake whitefish (Coregonus clupeaformis), bull trout (Salvelinus confluentus), lake trout ( $S$. namaycush) and kokanee (O nerka; Plate et al., 2012).

Regulation of Peace River flows has led to geomorphological changes of the river channel as a result of the interaction between reduced freshet flows, sediment inputs from tributaries downstream of the dam, and scouring by ice during breakup events (Church, 2014). The channel has narrowed, some side channels have become abandoned, and riparian vegetation has encroached into the former floodplain.

These changes have resulted in changes to fish habitat particularly in the $40 \mathrm{~km}$ reach below the dam before the first major tributary. The absence of freshet flows has likely reduced the seasonal availability of side-channel and ephemeral flood plain habitats that can be important for spring spawners, and can serve as nursery habitat for small fish. Large diurnal variation in flow resulting from hydropeaking has probably reduced the suitability of shoreline habitats. Water clarity in the reach below the dam has also likely increased over historical conditions as a result of the trapping of sediment in the reservoirs, although downstream tributaries are significant sources of sediment to the mainstem (Church, 2014).

Peace River below the dams supports populations of arctic grayling, bull trout, mountain whitefish (Prosopium williamsoni) and rainbow trout $(O$. mykiss) that are valued by indigenous peoples and recreational anglers, as well as 28 other species that are less frequently or not used. Fish populations in the Peace River have been assessed with a monitoring program that was able to generation adult population estimates for two of the key species of management interest, and catch-per-effort data for some others (Golder \& Gazey, 2018). Surveys suggest fish abundance is much higher in the $100 \mathrm{~km}$ below the dams than at locations further downstream, despite the highly modified flow regime. The abundance of small or juvenile fish in the reach below the dam is lower than at locations further downstream which may be the result of the changes in habitat described above (Mainstream Aquatics, 2012). Further downstream, the fish community becomes more diverse both in terms of the number of species, and the presence of earlier life stages and smaller species. However, the absence of comparable data from the pre-regulation period weakens any inference about the role of flow regulation on fish distribution or abundance as some of these patterns may have been due to pre-existing longitudinal variation in the fish community, as well as the result of recruitment from key tributary streams located downstream of the dams.

The construction and operation of the Site $\mathrm{C}$ dam is expected to further impact fish communities of the Peace River through the conversion of a further $80 \mathrm{~km}$ of river to reservoir, the inundation of the lower reaches of two important tributary streams, and the potential barrier the dam will present to those fish that use the Peace River as a migratory corridor.

A variety of tools were used to predict effects of the new dam on species of management interest for the environmental assessment of this project (JRP, 2014). Comparative analyses of existing reservoirs were used to make inferences about the future reservoir, and for fish living downstream from the dam a foodweb model was used to predict changes in energy flow in the aquatic community (BC Hydro, 2012). For migratory species a suite of life history studies that have taken advantage of recent advances in genetic analysis, telemetry, and the isotopic analysis of otoliths (Clarke et al., 2007; Taylor et al., 2014; Harrison et al., 2019) to supplement more traditional surveys. Those studies have highlighted the role of tributary streams as spawning, nursery, and feeding habitats, the extensive movements of some individuals between the tributaries and the mainstem, and the use of the mainstem as a migratory corridor for fish that move among tributaries. That knowledge, coupled with the location of key tributaries in relation to the new dam has led to specific predictions about the risks the dam poses to each population. Multiyear baseline monitoring of the populations is currently in place and will form the basis for the evaluation of effects and possible mitigation measures (BC Hydro, 2015; Golder \& Gazey, 2018). 


\section{Observations on large hydroelectric systems and the management of aquatic ecosystems}

The imposition of a mainstem dam on a large river triggers a series of changes to aquatic ecosystems that are difficult to reconcile with goals of maintaining natural ecosystem processes, or policies of "no net loss" of specific ecosystem services. Given the extent of the ecological changes, and a usually complex socio-economic milieu that surrounds these projects, a successful management approach is most likely when water management for environmental purposes is integrated with other services that water in the river can provide (Capon \& Capon, 2017). In the cases described here, this approach has generally resulted in the development of water management schemes that attempt to balance generation needs with flow, passage, and habitat requirements for a few fish species of interest or concern to stakeholders, First Nations, or regulatory agencies, as opposed to more vague and difficult to implement goals such as "ecosystem health" and its variants. The following sections are observations on some key management issues arising from the case histories.

Environmental flows for large hydroelectric developments

Environmental flows have a goal of maintaining or enhancing the ecosystem services provided by managed rivers, whether that be fish for use, habitats for wildlife, or access to water for human or other needs. As there are a variety ecosystem processes maintained by the seasonal hydrological regime of rivers, the use natural flow regime of rivers as a template for the management of regulated systems has gained popularity since the introduction of the natural flow paradigm by Poff et al. (1997). While this "nature knows best" approach has intuitive appeal, it is often infeasible in integrated hydropower systems where large spatial coherence in seasonal flows means that there are periods when water availability exceeds electrical demand, and other seasons when the opposite occurs. This is the case in western North America, where streamflows of large rivers are dominated by a large snowmelt-driven freshet in the spring months, followed by relatively low flows for the rest of the year. In BC, electrical demand is greatest in winter, when flows are the lowest; thus the electrical energy network is reliant on storage of freshet waters for generation at other times of the year. As a result, adherence to the natural flow regime for setting environmental flows directly conflicts with energy demand.

For situations where the natural flow regime is not a realistic baseline, so-called "designed" flow regimes may be implemented to achieve ecological goals while sustaining some of the other services resulting from river regulation (Acreman et al., 2014). Flows designed for specific ecosystem services, such as the maintenance of target fish populations, may be significantly different than the pre-development flow regime. Implementation of designed flows may lead to changes in ecological processes that are tied to natural variation in flows. In particular, natural freshet volumes are often greatly reduced in large regulated rivers and that usually triggers a sequence of geomorphological and ecological changes to the river and its valley (Kondolf et al., 2019). For example, high flows released into the Nechako River for the specific purpose of cooling the river for migrating sockeye salmon begin in late July, 1-2 months later than the natural freshet (Fig. 2). This has allowed aquatic vegetation to become established on gravel bars that would have previously been inundated in the spring by the freshet. Vegetation encroachment has contributed to a reduction in diversity of fish habitats, including the isolation of side channels, and the armouring of previously alluvial channels by the root systems of woody perennials (Rood, 1987). However, the flow regime for the Nechako River was designed specifically for chinook and sockeye salmon requirements and targets for these populations have been achieved despite changes to river ecosystem processes (NFCP, 2016).

Although there are many methods or models for evaluating environmental flows, few were designed for, or have been tested on, large rivers. The utility of different approaches to assessing the effects of altered or regulated flows in large rivers is dependent on whether the processes being modelled are sufficiently linked to the ecological services or management goals for the river. Many models or methods developed in small-medium sized rivers are explicitly or implicitly based on a presumed relation between abundance of particular species (usually fish) and some metric of the amount of suitable, or good, physical habitat (Williams et al., 2019) under the assumption that the supply 
of these habitats limits the size of target populations. Habitat is usually defined in terms of hydraulic conditions (depth, velocity) and cover. This approach is relevant to fish species (particularly salmonids) that defend space for spawning or feeding or can be used to predict changes in fish community composition based on general habitat preferences (Lamouroux \& Olivier, 2015). However, in large rivers, it is unclear whether physical space is limiting, relative to other factors such as food web or trophic interactions or the possibility that the availability of tributary habitats, where recruitment may occur, is actually limiting populations.

In the case of rivers with anadromous salmon, physical habitat simulation is commonly used to compute the amount of habitat suitable for foraging juvenile fish as a function of flow, particularly during the summer growing season. These fish are small $(<100 \mathrm{~mm}$ in length $)$ and are restricted by their size and swimming capability to slower-moving waters. For large rivers, physical habitat simulations based on small fish often predict suitable habitat will be maximized at very low flows, far below the natural flows during the summer growing season. Physical habitat simulation was used for both the Nechako and Bridge Rivers in the 1980s and 1990s, respectively, and in both cases model results suggested that diversions in excess of $90 \%$ would not impair juvenile salmon habitat availability (DFO, 1984; Bradford et al., 2011). However, the supposition that salmon population productivity would be maintained at these very low flows was not accepted by regulators and stakeholders due the uncertainties about the predictions, and the likelihood that other ecological processes, including those that also would contribute to maintaining salmon populations, would be at risk (Healey, 1998; Failing et al., 2004). In both cases, higher flows and adaptive management regimes were negotiated to reduce the uncertainty in about the effects of very low flows on fish populations of concern.

The environmental assessment of the Site $\mathrm{C}$ dam on the Peace River required predictions of changes in fish communities in the river below the new dam. Although the new dam has limited storage and the seasonal variation in flow will be similar to the predam condition, there will be an increase in the daily variation in flow associated with hydropeaking, and likely some effects on lower trophic levels downstream of the dam (DFO, 2014b). In addition to life history analyses, the proponents used ECOPATH, a mass balance food web model (Christensen \& Walters, 2004) to inform predictions of the range of potential changes in the abundance of the key species in the reach below the dam, across nine scenarios reflecting a range of assumptions about changes in primary production and fish response due to the project (BC Hydro, 2012; ESSA et al., 2012). Food web based approaches to flow management may be appropriate for large rivers where biotic interactions among a larger species pool may be more important than in smaller streams where physical habitat may dictate fish abundance (Robson et al., 2017); however, its application in river settings is limited to date (e.g. Warren et al., 2014). The mass balance food web approach provided insights on the range of possible future conditions both within the proposed reservoir and below the dam, but is a major simplification of the complexities. It is uncertain whether the steady state modelling approach is appropriate in an open system such as below a hydropeaking facility, particularly when some of the key species have complex life histories and patterns of habitat use (DFO, 2014b). Other approaches (e.g. detailed models of bull trout over their entire life history, including hypotheses about the effectiveness of fish passage measures) were used as additional lines of evidence in the environmental assessment (ESSA Technologies Ltd., 2012).

Although significant effort is placed in making predictions about river regulation on aquatic resources during environmental assessments or other exercises, the use of monitoring or followup data to test predictions has occurred infrequently (Hecky et al., 1984; Rosenberg et al., 1987; Souchon et al., 2008) and this has hindered the advancement of environmental science related to the impacts of hydroelectric projects. An example of the evaluation of an assessment model is provided by Lamouroux et al. $(1999,2015)$ who tested hydraulic models and found they were successful in predicting changes in community structure before and after flow changes in large French river. The success of models was related to the known variation in life history and a wide range of habitat preferences within the resident fish community. In contrast, in the Bridge River, the prediction that the reduction in suitable hydraulic habitat for small fish at higher flows would result in a reduction in fish populations has not been supported by initial 
monitoring results (Bradford et al., 2011). Further opportunities for testing predictions for both the Nechako and Bridge Rivers exist as lengthy datasets have been collected. Extensive baseline monitoring data is being collected on the Peace River and that should set the stage for a robust evaluation of the predictions that were made during the environmental assessment process for the Site C dam (BC Hydro, 2015). Pre- and post-project comparisons are not possible for the Bridge and Nechako Rivers due to the lack of quality baseline data.

In summary, predicting the effects of regulated flows on specific components of aquatic ecosystems in large rivers is particularly challenging because the "flow-ecology" relationships for key ecological resources are largely unknown (Davies et al., 2014). Although flow is often characterized as the master variable in rivers, McManamay et al. (2016) note that the dam itself may be pre-eminent, through its effects on other river processes such as water temperature and quality, sediment regimes and connectivity. The relative importance of aspects of flow, in relation to changes imposed by the dam will be site-specific, and potentially difficult to generalize across systems. In extreme cases, such as the reach of the Bridge River that received no water from the dam, there is some certainty that ecological conditions can be mitigated with flow management; however, there is likely a vast middle ground where the effects of flow on key indicators is highly uncertain due the interactions of flow with the effects of the dam itself (Healey, 1998).

Adaptive management: management panacea or kicking the can down the road?

When faced with significant uncertainty associated with predicting the ecological impacts of human activities on social and ecological systems, adaptive management (AM) is often proposed as an appropriate management regime to reduce uncertainty, and foster informed and efficient decision making (Murray et al., 2015). In current use, adaptive management usually refers to the use of monitoring data to learn about the response of the social-ecological system to management interventions. In its most rigorous form an AM trial is a pre-planned experiment, often guided by ecosystem modelling, with treatments designed to resolve key uncertainties. AM can also refer to postimplementation assessment of management policies after review of monitoring findings (Murray et al., 2015). The challenges of fully implementing AM are well documented (Walters, 1997), and Konrad et al. (2011) provide examples in the context of flow experiments in regulated rivers. Those challenges often include insufficient institutional and logistical support, lack of leadership within agencies and among stakeholders, and an inadequate experimental and monitoring plan (Rist et al., 2012).

Adaptive management has been instituted for ongoing water management planning in a number of settings (Allan \& Watts, 2018). Hydroelectric infrastructure is particularly amenable to AM trials as flow releases can potentially be controlled, within the constraints of the facility and needs for water. Natural variation in reservoir and tributary inflows can also generate contrasting conditions that may be informative (Alexander et al., 2006; Webb et al., 2017).

Murray et al. (2015) note that "adaptive management is not a panacea for uncertainty". They considered AM to be most effective when there is a base of ecological knowledge to allow for the development of relevant hypotheses, and there is potential to implement a sufficiently powerful monitoring program. Careful consideration of the inherent variability in the indicator being used to evaluate performance (such as fish abundance) is needed as the influence of the management intervention relative to other sources of variation as these factors can greatly influence utility of the experiment in detecting discriminating among hypotheses. Since most AM experiments for flow regulation in large rivers cannot be replicated, they tend to be timeseries designs ("Before-After"). Analyses of optimal experimental designs based on fish abundance as the indicator suggest many years, and perhaps decades, may be required before sufficient data can be obtained to resolve hypotheses of flow effects on the aquatic ecosystem (Korman \& Higgins, 1997; Bradford et al., 2005). Indicators that are more responsive to management actions, such as fish behaviour or survival at short time intervals, are likely to require less data to be informative, and may allow for more elaborate experimental designs (Walters et al., 1989). The lengthier the AM experiment, the greater the risk that some aspect of the environment, other than flow regulation or facility operations, will change and potentially confound the interpretation of the effects of the management intervention. Although non-stationarity in the environment can sometimes be 
accounted for through the use of control sites or other information (Walters, 1986), for large ecosystems this is not always possible. In the case of Nechako River chinook salmon, Bradford (1994) used the abundance of salmon in other Fraser River watersheds as controls to account for common variation in ocean survival and fishing mortality when comparing chinook salmon productivity to variation in flow and other factors in the Nechako River. However, for the Peace River, there is no other large river in the region, nor is there any evidence to suggest there is a common environmental driver that would warrant using a smaller river as a control replicate.

A sometimes underappreciated aspect of AM is the socio-economic system that complements the ecosystems affected by management actions. Large-scale AM programs, such as those for large hydroelectric developments, can take years or decades to yield sufficient information, and during that time considerable evolution of the social-economic context can also occur. This can include changes in the participants in AM from those that originally conceived it, changing social priorities, and new legal and policy requirements of governments (Tyre \& Michaels, 2011). This evolution of the social context may render adaptive management more of a journey than a structured whole-ecosystem experiment that leads to tidy dataset to resolve the original ecological uncertainty. This is the case for the Bridge River, as few of the original technical committee that designed the experiment are still connected to it, and the government agencies that were initially involved have redirected staff to other priorities. Increased participation by First Nations has resulted in an evolution in both the values associated with the adaptive management program, and the level of participation in the process (Satterfield et al., 2013). Further, there was an ongoing tension between community members wishing to engage in habitat or fish population restoration activities, and scientists who saw this as potentially corrupting the design of the flow experiment. Despite these challenges, the core monitoring program has been sustained over nearly 25 years, due in part to the continuity of key individuals in maintaining the program, and from the benefit the process has provided to the ongoing relationship between BC Hydro and affected communities of the area (Failing et al., 2013).

For the Nechako River, the discovery of the poor status of the White Sturgeon population and the listed of the population as endangered in 2006 may force managers into revisiting the water management regime and possibly redesigning the adaptive management program to include sturgeon along with salmon. Although considerable information on salmon populations has been gathered, the recent reduction in the collection of salmon monitoring data will increase the uncertainty in evaluating the effects of future changes in the flow regime.

The combination of large ecosystems and correspondingly large infrastructure, and the challenges of monitoring the effects of policy alternatives on ecosystem components of interest increases the risks associated with using AM as a management tool for large river hydropower. The use of AM to resolve uncertainty about project impacts may conflict with the application of the precautionary principle that guides regulators when considering project licensing and the design of mitigation measures (Olszynski, 2010). Alternatives to AM for dealing with uncertainty should be carefully considered in the contexts of the risks of successfully resolving that uncertainty. These risks extend beyond the ecosystem and economic risks that might normally be considered, to a more expansive consideration of likelihood of implementing and successfully completing an AM program.

A plea for quantitative life history studies

The goal of adaptive management is to reduce uncertainty about the response of the ecosystem to management measures, often by monitoring the responses of key populations before and after interventions. In the previous section I have argued that AM experiments for dams and river regulation in large rivers are likely to be of long duration and there is uncertainty about the success of their implementation. Part of the challenge is that ecosystem services of most interest tend to be the abundance and productivity of large, long-lived, fish species than can be difficult to sample, and require a long series of data before relations between management actions and population trends or status are revealed.

An alternative approach to reducing uncertainty is to use existing and new knowledge on the ecosystem and the effects of hydroelectric development in a structured process (Gillson et al., 2019). The formal summary and analysis of existing knowledge in a systematic review can be useful, but may be limited by 
site-specific and highly variable nature of responses of ecosystems to water management measures, which limits their transferability to new sites (Poff \& Zimmerman, 2009). However, an approach that incorporates expert, local and empirical knowledge can result in the incorporation of site-specific information that may be more informal in nature. Williams et al. (2019, Chap. 9) outline the steps in such an approach, and propose the use of Bayesian Belief Networks to formalize the incorporation various sources of information into the analysis. Although uncertainty will remain, the process is far less onerous than an AM trial and should have a higher likelihood of being successfully concluded, and in a much shorter timeline. As the input information and judgments are coded into the model, the outcomes are transparent, repeatable, and can be readily updated with new information.

An important component of this work are quantitative life history investigations to identify movement and migrations, habitat use at local and larger scales, diet, and other environmental preferences that will inform how river regulation may affect population status. Often, the early life stages of fish are the most sensitive to changes in environmental conditions as these stages are limited to habitats that are most vulnerable to effects of flow regulation. Larval and juvenile stages are also more likely to be affected by changes in food availability or predation risk relative to adult fish (Pine et al., 2009). However, long-term monitoring of the early life stages of fish in large rivers is challenging as abundance can be highly variable in space and time and sampling can be difficult. Consequently adult population monitoring is sometimes relied on, although this can be an inefficient way to gain understanding of the recruitment process. For example, attempts are being made to estimate recruitment of mountain whitefish in the Peace River based on the adult sampling program; however, preliminary results suggest low catchability may ultimately limit the precision of those estimates (Golder \& Gazey, 2018).

An understanding of intrapopulation diversity is also an important consideration as segments of the population may be differentially exposed to the effects of flow regulation. For example, in the Nechako River and Bridge Rivers, there is a significant downstream migration of juvenile chinook salmon that occurs soon after young fish emerge from the spawning areas, and these fish would not be exposed to regulated river conditions for more than a few weeks immediately after their emergence. There is also a component of the population that resides in the river for a year, for which considerable effort has been expended in setting flow regimes designed to provide suitable habitat conditions (Mundie \& Bell-Irvine, 1986; Failing et al., 2004). However, the relative importance of these different life history types to adult production has not been determined; such information would be invaluable in ranking alternative water management scenarios. Recent developments in genetic, isotopic, and elemental analyses now make such analyses possible (e.g. Brennan et al., 2019). Similarly, studies in the Peace River have revealed the importance of tributaries as spawning, nursery and feeding habitats for some of the key species, and that there are extensive migrations among habitats for some individuals in each population (Harrison et al., 2019). These findings suggest that connectivity, rather than regulated flow regimes may be critical to sustain components of these populations (BC Hydro, 2012).

In all three case histories long-term monitoring, using standard methods, was initiated to help resolve uncertainties about river regulation on fish populations but such inferences could have been aided by a deeper understanding of life history and habitat use. Studies that have been conducted for the new Peace River dam illustrate that there is now a growing suite of innovative methods, that when coupled with traditional sampling, can be effective in providing the information needed to estimate the effects of river regulation on target fish populations.

\section{Summary}

In this review, examples are provided of how mainstem dams result in extensive changes to river ecosystems that are difficult to reconcile with legislative, policy or aspiration goals of retaining all elements of the natural aquatic ecosystem. In these situations, priority is set on specific ecosystem services. In Canada, legal and policy flexibility allows for this transformation of large river ecosystems, although the challenge is in finding a satisfactory balance between the human use of water and changes to the environment. 
I document how it is particularly difficult to predict change in fish populations in larger rivers when those populations have migratory patterns, diversity in life history and habitat use within populations, or are part of complex food webs that require predictions of change in other fish populations. Further, the likelihood that population monitoring and adaptive management programs will be successful is unclear due to the likely need for lengthy and extensive sampling programs, institutional difficulties, and other constraints in the social-economic realm.

Thus it may be more important to rely on formalized expert-driven processes, informed by existing and new information for environmental decision making (e.g. Barton et al., 2020). Follow-up monitoring can provide a means to track major changes in desired ecosystems. However, in large rivers, predictions of effects will always be uncertain, and monitoring can take considerable time and effort to yield reliable results; the discourse among project proponents, regulatory agencies and affected parties should reflect that uncertainty.

Finally, we are currently living in a period of rapidly changing climate that can be expected to affect the quantity and timing of water available for power generation, and the environmental conditions for species inhabiting waters regulated for hydropower. Although annual streamflow in coastal and northern $\mathrm{BC}$ is not expected to decline significantly (Schnorbus et al., 2012), extreme streamflow events may become more common, and river water temperatures are expected to rise during the summer months with increasing air temperatures, and decreasing summer flow (Pike et al., 2010). This suggests management regimes design to meet environmental goals will need to incorporate predicted changes in climate, and be adaptive and flexible as climate changes are realized. Marmorek et al. (2019) suggests many of the steps of adaptive management (clear development of objectives, system modelling, monitoring for learning and adaptive feedback) are well suited as strategies for adapting to climate change. Perhaps the next challenge is to create the flexibility within our legal, regulatory and socio-economic systems so we can respond to challenges that climate change will pose (Horne et al., 2019).

Acknowledgements This review is dedicated to my friend and colleague Paul Higgins, with whom I shared many discussions about dams and fish both on the streambank and in the boardroom. Dylan Cunningham prepared the map and Douglas Braun and two reviewers provided comments on a draft manuscript.

Open Access This article is licensed under a Creative Commons Attribution 4.0 International License, which permits use, sharing, adaptation, distribution and reproduction in any medium or format, as long as you give appropriate credit to the original author(s) and the source, provide a link to the Creative Commons licence, and indicate if changes were made. The images or other third party material in this article are included in the article's Creative Commons licence, unless indicated otherwise in a credit line to the material. If material is not included in the article's Creative Commons licence and your intended use is not permitted by statutory regulation or exceeds the permitted use, you will need to obtain permission directly from the copyright holder. To view a copy of this licence, visit http://creativecommons.org/licenses/by/4.0/.

\section{References}

Acreman, M., A. H. Arthington, M. J. Coloff, C. Couch, N. D. Crossman, F. Dyer, I. Overton, C. A. Pollino, M. J. Stewardson \& W. Young, 2014. Environmental flows for natural, hybrid, and novel riverine ecosystems in a changing world. Frontiers in Ecology and the Environment 12: 466-473.

Alcan, 2007. BC Hydro/Alcan 2007 Electricity Purchase Agreement. https://www.bcuc.com/Documents/ Proceedings/2007/DOC_16636_B2-1_Alcan_Report_ 2007_EPA.pdf.

Alexander, C. A. D., C. N. Peters, D. R. Marmorek \& P. Higgins, 2006. A decision analysis of flow management experiments for Columbia River mountain whitefish management. Canadian Journal of Fisheries and Aquatic Science 63: 1142-1156.

Allan, C. \& R. Watts, 2018. Revealing adaptive management of environmental flows. Environmental Management 61: 520-533.

Barton, D. N., H. Sundt, A. A. Bustos, H.-P. Fjeldstad, R. Hedger, T. Forseth, B. Kohler, Ø. Aas, K. Alfredson \& A. L. Madsen, 2020. Multi-criteria decision analysis in Bayesian networks - diagnosing ecosystem service tradeoffs in a hydropower regulated river. Environmental Modelling and Software 124: 104604.

BC Hydro, 2012. Future aquatic conditions in the Peace River. Site C Clean Energy Project, EIS technical appendix: future aquatic conditions, Volume 2, Appendix P, Part 3. https://iaac-aeic.gc.ca/050/evaluations/document/ 93686 ? culture $=$ en - CA.

BC Hydro, 2015. Fisheries and aquatic habitat monitoring and follow-up program. https://www.sitecproject.com/sites/ default/files/Fisheries-and-Aquatic-Habitat-Monitoringand-Follow-up-Program.pdf.

Benidickson, J., 2017. The evolution of Canadian water law and policy: securing safe and sustainable abundance. McGill Journal of Sustainable Development Law 13: 59-105. 
Bérubé, M., R. Verdon, G. Durocher \& J.-C. Guay, 2005. A comprehensive framework for assessing changes in fish habitat productive capacity resulting from large hydroelectric projects. Canadian Science Advisory Secretariat Research Document 2005/51.

Bradford, M. J., 1994. Trends in the abundance of Chinook Salmon (Oncorhynchus tshawytscha) of the Nechako River, British Columbia. Canadian Journal of Fisheries and Aquatic Science 51: 965-973.

Bradford, M. J., J. Korman \& P. S. Higgins, 2005. Using confidence intervals to estimate the response of salmon populations (Oncorhynchus spp.) to experimental habitat alterations. Canadian Journal of Fisheries and Aquatic Science 62: 2716-2726.

Bradford, M. J., P. S. Higgins, J. Korman \& J. Sneep, 2011. Test of an experimental flow release in a British Columbia river: does more water mean more fish? Freshwater Biology 56: 2119-2134.

Brennan, S. R., D. E. Schindler, T. J. Cline, T. E. Walsworth, G. Buck \& D. P. Fernandez, 2019. Shifting habitat mosaics and fish production across river basins. Science 364 : 783-786.

Brett, J. R., 1957. Salmon research and hydro-electric power development. Bulletin of the Fisheries Research Board of Canada 114: 26.

British Columbia Utilities Commission (BCUC), 1994. Kemano Completion Project review: report and recommendations to the Lieutenant Governor in Council. British Columbia Utilities Commission, Vancouver, BC.

Canada Energy Regulator (CER), 2017. Canada's renewable power landscape- energy market analysis 2017. https:// www.cer-rec.gc.ca/nrg/sttstc/lctrct/rprt/ 2017 cndrnwblpwr/2017cndrnwblpwr-eng.pdf.

Canadian Hydropower Association (CHA), 2016. Submission on the review of the Fisheries Act. https://www. ourcommons.ca/Content/Committee/421/FOPO/Brief/ BR8692425/br-external/ CanadianHydropowerAssociation-e.pdf.

Capon, S. J. \& T. R. Capon, 2017. An impossible prescription: why science cannot determine environmental water requirements for a healthy Murray-Darling basin. Water Economics and Policy 3: 1650037.

Christensen, V. \& C. J. Walters, 2004. Ecopath with Ecosim: methods, capabilities and limitations. Ecological Modelling 172: 109-139.

Church, M., 2014. The regulation of Peace River: a case study for river management. Wiley, New York.

Clarke, K. D. \& M. J. Bradford, 2014. A review of equivalency in offsetting policies. DFO Canadian Science Advisory Secretariat Research Document 2014/109.

Clarke, A. D., K. H. Telmer \& J. M. Shrimpton, 2007. Habitat use and movement patterns for a fluvial species, the Arctic grayling in a watershed impacted by a large reservoir: evidence from otolith microchemistry. Journal of Applied Ecology 44: 1156-1165.

Committee on the Status of Endangered Wildlife in Canada (COSEWIC), 2012. COSEWIC assessment and status report on the White Sturgeon Acipenser transmontanus in Canada. Committee on the Status of Endangered Wildlife in Canada, Ottawa.
Davies, P. M., R. J. Naiman, D. M. Warfe, N. E. Pettit, A. H. Arthington \& S. E. Bunn, 2014. Flow-ecology relationships: closing the loop on effective environmental flows. Marine and Freshwater Research 65: 133-141.

DFO, 1984. Towards a fish habitat decision on the Kemano Completion Project: a discussion paper. https://wavesvagues.dfo-mpo.gc.ca/Library/40588208.pdf.

DFO, 1986. Policy for the management of fish habitat. Fish Habitat Management Branch, Fisheries and Oceans Canada, Ottawa, ON.

DFO, 2014a. A science-based framework for assessing changes in productivity, within the context of the amended Fisheries Act. DFO Canadian Science Advisory Secretariat Science Advisory Report 2013/071.

DFO, 2014b. Technical review of the effects of the Site C clean energy project on fish and fish habitat of the Peace River, British Columbia. Canadian Science Advisory Secretariat Science Response 2014/011.

DFO, 2019. Fish and fish habitat protection policy statement. https://www.dfo-mpo.gc.ca/pnw-ppe/policy-politiqueeng.html.

ESSA Technologies Ltd., 2012. Using single species population models of bull trout, kokanee and Arctic grayling to evaluate Site C passage alternatives. Site C Clean Energy Project, BC Hydro. Environmental Impact Assessment. Volume 2 Appendix Q Fish Management Plan, Part 3. Prepared for BC Hydro. December 2012. 77 p. https://iaacaeic.gc.ca/050/documents_staticpost/63919/85328/Vol2_ Appendix_Q.pdf.

Evenden, M. D., 2004. Fish versus power: an environmental history of the Fraser River. Cambridge University Press, Cambridge, UK.

Failing, L., G. Horn \& P. Higgins, 2004. Using expert judgment and stakeholder values to evaluate adaptive management options. Ecology and Society 9(1): 13.

Failing, L., R. Gregory \& P. Higgins, 2013. Science, uncertainty, and values in ecological restoration: a case study in structured decision-making and adaptive management. Restoration Ecology 21: 422-430.

Geen, G. H., 1974. Effects of hydroelectric development in western Canada on aquatic ecosystems. Journal of the Fisheries Research Board of Canada 31: 913-927.

Gillson, L., H. Biggs, I. P. J. Smit, M. Virah-Sawmy \& K. Rogers, 2019. Finding common ground between adaptive management and evidence-based approaches to biodiversity conservation. Trends in Ecology and Evolution 34: 31-44.

Golder Associates Ltd. \& W.J. Gazey, 2018. Peace River large fish indexing survey-2017 investigations. Report prepared for BC Hydro, Vancouver BC. https://www.sitecproject. $\mathrm{com} /$ sites/default/files/mon-2-task-2a-peace-river-largefish-indexing-survey-2017-annual-report.pdf.

Harrison, P. M., R. A. Keeler, D. Robichaud, B. Mossop, M. Power \& S. J. Cooke, 2019. Individual differences exceed species differences in the movements of a river fish community. Behavioural Ecology 30: 1289-1297.

Hawkshaw, S. C. F., M. P. Gillingham \& J. M. Shrimpton, 2014. Habitat characteristics affecting occurrence of a fluvial species in a watershed altered by a large reservoir. Ecology of Freshwater Fish 23: 383-394. 
Healey, M. C., 1998. Paradigms, policy, and prognostications about the management of watershed ecosystems. In Naiman, R. J. \& R. E. Bilby (eds), River ecology and Management. Springer, New York: 662-682.

Hecky, R. E., R. W. Newbury, R. A. Bodaly, K. Pataias \& B. M. Rosenberg, 1984. Environmental impact prediction and assessment: the Southern Indian Lake experience. Canadian Journal of Fisheries and Aquatic Sciences 41: 720-952.

Hildebrand, L. R., A. D. Schreier, K. Kepla, S. O. McAdam, J. McLellan, M. J. Parsley, V. L. Paragamian \& S. P. Young, 2017. Status of White Sturgeon (Acipenser transmontanus Richardson, 1863) throughout the species range, threats to survival, and prognosis for the future. Journal of Applied Ichthyology 32(S1): 261-312.

Hirst, S. M., 1991. Impacts of the operation of existing hydroelectric developments on fishery resources in British Columbia. Volume I: Anadromous salmon. Canadian Manuscript Report of Fisheries and Aquatic Sciences 2093.

Horne, A. C., R. Nathan, N. L. Poff, N. R. Bond, J. A. Webb, J. Wang \& A. John, 2019. Modeling flow-ecology responses in the anthropocene: challenges for sustainable riverine management. Bioscience 69: 789-799.

International Pacific Salmon Fisheries Commission (IPSFC), 1953. A review of the sockeye salmon problems created by the Alcan project in the Nechako River watershed. IPSFC, New Westminster, BC.

Jarmovic, L. \& D. Rowland, 1988. Review of chinook salmon escapements in the Nechako River. Canadian Manuscript of Fisheries and Aquatic Sciences, British Columbia: 1963.

Joint Review Panel (JRP), 2014. Report of the Joint Review Panel - Site C Clean Energy Project. https://iaac-aeic.gc. ca/050/documents/p63919/99173E.pdf.

Kondolf, G. M., R. Loire, H. Piégay \& J. R. Malavoi, 2019. Dams and channel morphology. In Williams, J. G., P. B. Moyle, J. A. Webb \& G. M. Kondolf (eds), Environmental flow assessment: methods and applications. Wiley, Hobokan, NJ: 143-161.

Konrad, C. P., J. D. Olden, D. A. Lytle, T. S. Melis, J. C. Schmidt, E. N. Bray, M. C. Freeman, K. B. Gido, N. P. Hemphill, M. J. Kennard, L. E. McMullen, M. C. Mims, M. Pyron, C. T. Robinson \& J. G. Williams, 2011. Large-scale flow experiments for managing river systems. BioScience 61: 948-959.

Korman, J. \& C. Walters, 2000. Nechako River White Sturgeon recovery planning: summary of stock assessment and Oct. 2-3, 2000 workshop. Contract report prepared for BC Fisheries, Victoria BC. https://www. nechakowhitesturgeon.org/uploads/Reports/ KormanReport.pdf.

Korman, J. \& P. S. Higgins, 1997. Utility of escapement time series data for monitoring the response of salmon populations to habitat alteration. Canadian Journal of Fisheries and Aquatic Science 54: 2058-2067.

Lamouroux, N. \& J.-M. Olivier, 2015. Testing predictions of change in fish abundance and community structure after flow restoration in four reaches of a large river (French Rhône). Freshwater Biology 60: 1118-1130.

Lamouroux, N., J. M. Olivier, H. Persat, M. Pouilly, Y. Souchon \& B. Statzner, 1999. Predicting community characteristics from habitat conditions: fluvial fish and hydraulics. Freshwater Biology 42: 275-299.

MacKinnon, D., L. Edgeworth \& R. E. McLaren, 1961. An assessment of the Jones Creek spawning channel. Canadian Fish Culturist 30: 3-14.

Mainstream Aquatics, 2012. Site C clean energy project fish and fish habitat technical data report. Contract report prepared for BC Hydro, Vancouver, BC. https://iaac-aeic.gc.ca/050/ documents_staticpost/63919/85328/Vol2_Appendix_O. pdf.

Marmorek, D., M. Nelitz, J. Eyzaguirre, C. Murray \& C. Alexander, 2019. Adaptive management and climate change adaptation: two mutually beneficial areas of practice. Journal of the American Water Resources Association 55: 881-905.

McKenney, B. A. \& J. M. Kiesecker, 2010. Policy development for biodiversity offsets: a review of offset frameworks. Environmental Management 45: 165-176.

McManamay, R. A., S. K. Brewer, H. I. Jager \& M. J. Troia, 2016. Organizing environmental flow frameworks to meet hydropower mitigation needs. Environmental Management 58: 365-385.

McPhail, J. D., 2007. The freshwater fishes of British Columbia. University of Alberta Press, Edmonton.

Mullen-Dalmer, D., 2009. Case study 12. Bridge River Water Use Plan. In Hirji, R. \& R. Davis (eds), Environmental Flows in Water Resources Policies, Plans, and Projects. World Bank Environmental Department, Washington DC: 111-120.

Mundie, J. H. \& R. Bell-Irvine, 1986. Predictability of the consequences of the Kemano hydroelectric proposal for natural salmon populations. Canadian Water Resources Journal 11: 14-25.

Murray, C. L., D. R. Marmorek \& L. A. Greig, 2015. Adaptive management today: a practioners perspective. In Allen, C. R. \& A. S. Garmestani (eds), Adaptive Management of Social-ecological Systems. Springer, Berlin: 181-199.

Nechako Fisheries Conservation Program (NFCP), 2005. Nechako Fisheries Conservation Program technical data review 1988-2002. https://nfcp.org/uploads/technical_ review/NFCP_Technical_Data_Review_1988-2002_Full_ Report.pdf.

NFCP, 2016. Historical review of the Nechako Fisheries Conservation Program: 1987-2015. https://nfcp.org/uploads/ summary_reports/NFCP_History_Report_July_2016.pdf.

Olszynski, M. Z. P., 2010. Adaptive management in Canadian environmental assessment law: exploring uses and limitations. Journal of Environmental Law and Practise 21: 1.

Pike, R. G., T. E. Redding, R. D. Moore, R. D. Winker \& K. D. Bladon, 2010. Compendium of forest hydrology and geomorphology in British Columbia. B.C. Ministry of Forest Range, Forest Science Program, Victoria, B.C. and FORREX Forum for Research and Extension in Natural Resources, Kamloops, B.C. Land Management Handbook 66. www.for.gov.bc.ca/hfd/pubs/Docs/Lmh/Lmh66.htm.

Pine, W. E., S. J. D. Martell, C. J. Walters \& J. F. Kitchell, 2009. Counterintuitive responses of fish populations to management actions: some common causes and implications for predictions based on ecosystem modelling. Fisheries 34 : 165-180. 
Plate, E. M., R. C. Bocking \& D. J. Degan, 2012. Peace Project Water Use Plan: Monitoring Programs for the Peace Spill Protocol. https://www.bchydro.com/content/dam/ $\mathrm{BCHydro/customer-portal/documents/corporate/}$ environment-sustainability/water-use-planning/northerninterior/gmsmon-4-fish-index-final-2012-07-01.pdf.

Poff, N. L. \& J. K. H. Zimmerman, 2009. Ecological responses to altered flow regimes: a literature review to inform the science and management of environmental flows. Freshwater Biology 55: 194-205.

Poff, N. L., J. D. Allan, M. B. Bain, J. R. Karr, K. L. Prestegaard, B. D. Richter, R. E. Sparks \& J. C. Stromberg, 1997. The natural flow regime: a paradigm for river conservation and restoration. BioScience 47: 769-784.

Rist, L., B. M. Campbell \& P. Frost, 2012. Adaptive management: where are we now. Environmental Conservation 40: 5-18.

Robson, B. J., R. E. Lester, D. S. Baldwin, N. R. Bond, R. Drouart, R. J. Rolls, D. S. Ryder \& R. M. Thompson, 2017. Modelling food-web mediated effects of hydrological variability and environmental flows. Water Research 124: $108-128$.

Rood, K. M., 1987. The effects of regulation of flow in the Nechako River on channel morphology, sediment transport and deposition, and flushing flows. Expert report prepared for the Department of Fisheries and Oceans. https://wavesvagues.dfo-mpo.gc.ca/Library/40596588.pdf.

Rosenberg, D. M., R. A. Bodaly, R. E. Hecky \& R. W. Newbury, 1987. The environmental assessment of hydroelectric impoundments and diversions in Canada. Canadian aquatic resources. Canadian Bulletin of Fisheries and Aquatic Sciences 215: 71-104.

Satterfield, T., R. Gregory, S. Klain, M. Roberts \& K. M. Chan, 2013. Culture, intangibles, and metrics in environmental management. Journal of Environmental Management 117: $103-114$.

Saunders, J. O. \& M. M. Wenig, 2007. Whose water? Canadian water management and the challenges of jurisdictional fragmentation. In Bakker, K. (ed.), Eau Canada: the future of Canada's waters. UBC Press, Vancouver: 119-140.

Schnorbus, M., A. Bennett \& K. Werner, 2012. Impacts of climate change in three hydrologic regimes in British Columbia, Canada. Hydrological Processes 28: 1170-1189.

Souchon, Y., C. Sabaton, R. Deibel, D. Reiser, J. Kershner, M. Gard, C. Katopodis, P. Leonard, N. L. Poff, W. L. Miller \& B. L. Lamb, 2008. Detecting biological responses to flow management: missed opportunities; future directions. River Research and Applications 24: 506-518.
Stockner, J., A. Langston, D. Sebastian \& G. Wilson, 2005. The limnology of Williston Reservoir: British Columbia's largest lacustrine ecosystem. Water Quality Research Journal of Canada 40: 28-50.

Taylor, E. B., M. M. Yau \& A. B. Mattock, 2014. Population structure in three species of co-distributed salmonid fishes in the Peace River and tributaries near a major proposed hydroelectric development in northeastern British Columbia, Canada. River Research and Applications 30: 1120-1133.

Tyre, A. J. \& S. Michaels, 2011. Confronting socially generated uncertainty in adaptive management. Journal of Environmental Management 92: 1365-1370.

Walters, C., 1986. Adaptive management of renewable resources. MacMillan, New York.

Walters, C., 1997. Challenges in adaptive management of riparian and coastal ecosystems. Conservation Ecology 1(2): 1.

Walters, C. J., J. S. Collie \& T. Webb, 1989. Experimental designs for estimating transient responses to habitat alteration: is it practical to control for environmental interactions?, pp. 13-20. In: Levings, C. D. Holtby, L. B. \& M. A. Henderson (eds) Proceedings of the National Workshop on Effects of Habitat Alteration on Salmonid Stocks. Canadian Special Publications Fisheries and Aquatic Sciences 105.

Warren, D. R., C. J. Harvey, M. M. McClure \& B. L. Sanderson, 2014. Use of ecosystem-based model to evaluate alternative conservation strategies for juvenile Chinook Salmon in a headwater stream. North American Journal of Fisheries Management 34: 839-852.

Webb, J. A., R. J. Watts, C. Allan \& A. T. Warner, 2017. Principles for monitoring, evaluation, and adaptive management of environmental water regimes. In Horne, A. C., J. A. Webb, M. J. Stewardson, B. Richter \& M. Acreman (eds), Water for the Environment. Academic Press, London: 599-623.

Williams, J. G., P. B. Moyle, J. A. Webb \& G. M. Kondolf, 2019. Environmental Flow Assessment: Methods and Applications. Wiley, Hobokan, NJ.

Windsor, J. E. \& J. A. McVey, 2005. Annihilation of both place and sense of place: the experience of the Cheslatta T'En Canadian First Nation within the context of large-scale environmental projects. The Geographical Journal 171: 146-165.

Publisher's Note Springer Nature remains neutral with regard to jurisdictional claims in published maps and institutional affiliations. 